\title{
RNA Synthesis and Degradation during Antibiotic Treatment and its Relation to Antibiotic-induced Lag
}

\author{
By T. D. BROCK *AND M. LOUISE BROCK \\ Department of Biology, Western Reserve University, \\ Cleveland 6, Ohio, U.S.A.
}

(Received 14, March 1961)

\begin{abstract}
SUMMARY
When growing cells of Escherichia coli were treated with chloramphenicol or erythromycin for $1 \mathrm{hr}$. and then suspended in antibiotic-free medium, there was a $45 \mathrm{~min}$. lag before growth resumed. By eliminating growth factors or other essential nutrients during antibiotic treatment, it was possible to show that the lag occurred only when ribonucleic acid (RNA) synthesis could take place and did not require the synthesis of deoxyribonucleic acid (DNA). This antibiotic-induced RNA was apparently abnormal and was degraded when the antibiotic was removed. This degradation is a hydrolytic process and does not require the presence of a complete growth medium. During the recovery from the antibiotic-induced lag, DNA and protein synthesis did not occur, but RNA synthesis occurred, even though this new RNA synthesis was not required for the lag to be overcome. When antibiotictreated cells were suspended in phosphate buffer, a decrease in optical density of the suspension occurred which resembled a lytic process, but lysis apparently did not occur. Although these results clarify considerably earlier observations on antibioticinduced lag, they leave unsolved the question of why the antibiotic-induced RNA is abnormal, and how it brings about the lag.
\end{abstract}

\section{INTRODUCTION}

Several years ago there were independent reports from several laboratories of accumulation of RNA and its subsequent degradation in chloramphenicol-inhibited cells (Hahn et al. 1957; Neidhardt \& Gros, 1957; Horowitz, Lombard \& Chargaff, 1958). The first two groups of workers showed that cells which had been treated with antibiotic, and had accumulated RNA, exhibited a lag before growth resumed when they were suspended in antibiotic-free medium. Although these workers had indirect evidence for the relation of this antibiotic-accumulated RNA to the subsequent lag, they supplied no direct evidence for this hypothesis.

The present work was begun when the authors (Brock \& Brock, 1959a) discovered that erythromycin and chloramphenicol were similar in action and began to compare a number of facets of erythromycin action with those of chloramphenicol. It was readily shown that erythromycin also brought about RNA accumulation, and erythromycin-treated cells also exhibited a lag when resuspended in antibiotic-free growth medium. The availability of a mutant of Escherichia coli $15 \mathrm{~T}^{-} \mathrm{U}^{-}$(Barner \&

* Present address : Department of Bacteriology, Indiana University, Bloomington, Indiana. 
Cohen, 1958), which requires thymine + uracil for growth, provided us with a tool for controlling RNA and DNA synthesis during antibiotic treatment and recovery, to show directly the involvement of RNA in antibiotic-induced lag. A preliminary report of this work has been presented (Brock \& Brock, 1960).

\section{METHODS}

Organisms. Escherichia coli strains $15 \mathrm{~T}-\mathrm{U}-$ and $\mathrm{T}-\mathrm{A}-\mathrm{U}-$ were kindly provided by Dr S. Cohen; $E$. coli $\mathrm{B}_{4}$ (prolineless) was obtained from Dr L. Frank, and $E$. coli ML 35, from Dr J. Monod. A methionine-requiring mutant of strain $15 \mathrm{~T}-\mathrm{U}-$ was isolated by the authors and is designated $\mathbf{T}-\mathrm{U}-\mathbf{M}-$.

Medium and growth conditions. A defined medium of the following composition was used (g.): $\mathrm{K}_{2} \mathrm{HPO}_{4}, 6 \cdot 0 ; \mathrm{KH}_{2} \mathrm{PO}_{4}, 3.0 \mathrm{NH}_{4} \mathrm{Cl}, 0.5 ; \mathrm{MgSO}_{4} .7 \mathrm{H}_{2} \mathrm{O}, 0 \cdot 1$; glucose, 4.0 ; distilled water to $1 \mathrm{l}$. Thymine and uracil were added to give final concentrations of 8 and $40 \mu \mathrm{g} . / \mathrm{ml}$. except in the radioactivity experiments. Arginine and methionine were added to final concentrations of $50 \mu \mathrm{g} . / \mathrm{ml}$., and proline to $100 \mu \mathrm{g} . / \mathrm{ml}$. except in the radioactivity experiments.

Growth was followed by measuring optical density (O.D.) at $420 \mathrm{~m} \mu$ on a Lumetron colorimeter.

Organisms were grown overnight in defined medium at $37^{\circ}$ on a rotary shaker, diluted into fresh medium to an optical density of 0.035-0.050, and dispensed $100 \mathrm{ml} . / 500 \mathrm{ml}$. flask. After logarithmic growth had been re-established, at approximately $0 . D .0 \cdot 150$, the suspensions were chilled and centrifuged, then washed twice with cold buffer of the following composition (g.): $\mathrm{K}_{2} \mathrm{HPO}_{4}, 6 \cdot 0 ; \mathrm{KH}_{2} \mathrm{PO}_{4}, 3.0$; distilled water, 11 . The organisms were then resuspended in fresh medium with and without various supplements at $37^{\circ}$ to O.D. $0 \cdot 150$ and replaced on the shaker for antibiotic treatment. This same procedure for washing suspensions was repeated after the antibiotic treatment.

Antibiotics. Chloramphenicol was purchased from Parke, Davis and Co., and erythromycin was a gift from Eli Lilly and Co. Stock solutions of these antibiotics were prepared in $50 \%(\mathrm{v} / \mathrm{v})$ aqueous ethanol, and these were diluted 1/100 upon addition to suspensions of organisms. Chloramphenicol was used at a final concentration of $50 \mu \mathrm{g} . / \mathrm{ml}$. and erythromycin at $1000 \mu \mathrm{g} . / \mathrm{ml}$.

Assays. For chemical assays of deoxyribonucleic acid (DNA), ribonucleic acid (RNA) and protein, $10 \mathrm{ml}$. samples were removed and chilled in an ice bath at $4^{\circ}$, centrifuged in the cold for $5 \mathrm{~min}$. at $13,000 \mathrm{rev} . / \mathrm{min}$., and washed in succession with $8 \mathrm{ml}$. volumes of cold $0.5 \mathrm{~N}-\mathrm{HClO}_{4}, 95 \%(\mathrm{v} / \mathrm{v})$ ethanol in water, and anhydrous ether. The residue was then air dried and extracted with $4 \mathrm{ml}$. of $0.5 \mathrm{~N}-\mathrm{HClO}_{4}$ at $90^{\circ}$ for $15 \mathrm{~min}$. The extracts were allowed to cool to room temperature and were then centrifuged. A $1 \mathrm{ml}$. sample of this supernatant was used for assay of DNA by the method of Burton (1956). A 1 ml. sample was diluted with $2 \mathrm{ml}$. of $0.5 \mathrm{~N}-\mathrm{HClO}_{4}$ for assay of RNA by the method of Chargaff \& Davidson (1955). For assay of protein by the method of Lowry (Lowry, Rosebrough, Farr \& Randall, 1951) the residue from the hot $\mathrm{HClO}_{4}$ extraction was suspended in $10 \mathrm{ml}$. of $\mathrm{N}-\mathrm{NaOH}$ and heated to $100^{\circ}$ for $1 \mathrm{hr}$; ; $1 \mathrm{ml}$. sample was used. Commercial preparations of DNA, RNA, and lysozyme were used as standards.

Radioactivity experiments. Thymine-2-14C (Volk Radiochemical Co., specific 
activity $1.0 \mathrm{mc} . / \mathrm{mM}$ ) was added to a concentration of $2 \mu \mathrm{g} . / \mathrm{ml}$., $1.15 \times 10^{4} \mathrm{c} . \mathrm{p} . \mathrm{m} . / \mathrm{ml}$. Uracil-2-14 $\mathrm{C}$ (Volk Radiochemical Co., specific activity $3 \cdot 2 \mathrm{mc} . / \mathrm{mm}$ ) was added to a concentration of $10 \mu \mathrm{g} . / \mathrm{ml} ., 1.95 \times 10^{5} \mathrm{c} . \mathrm{p} . \mathrm{m} . / \mathrm{ml}$. Proline (Schwartz Bioresearch, Mt Vernon, New York; specific activity $100 \mu \mathrm{c} . / \mathrm{mm}$ ) was added to a concentration of $45 \mu \mathrm{g} . / \mathrm{ml}$., $3.88 \times 10^{4}$ c.p.m. $/ \mathrm{ml}$. Sodium sulphate- ${ }^{35} \mathrm{~S}$ (Oak Ridge National Laboratories, carrier-free) was added at $8.64 \times 10^{4}$ c.p.m. $/ \mathrm{ml}$.

For measurement of incorporation of the radioactive compounds, washed organisms were resuspended in the appropriate medium, the radioactive compound added, and samples taken. In the case of uracil, $0.1 \mathrm{ml}$. samples were taken, cooled in an ice bath, and $0.9 \mathrm{ml}$. of cold $0.5 \mathrm{~N}-\mathrm{HClO}_{4}$ was added. For thymine, proline and sulphate, $1.0 \mathrm{ml}$. samples were taken, cooled, and $9.0 \mathrm{ml}$. of cold $0.5 \mathrm{~N}-\mathrm{HClO}_{4}$ added. After standing for $\mathbf{3 0} \mathrm{min}$. in the cold, the suspensions were filtered on membrane filters (Millipore type HA, $0.45 \mu$ ), washed twice with equal volumes of cold $0.5 \mathrm{~N}-\mathrm{HClO}_{4}$, and the filter disks glued to stainless steel planchets (Roberts et al. 1957).

In experiments in which the RNA was labelled with radioactive uracil during or before antibiotic treatment, uracil of a specific activity of $0.96 \mathrm{mc} . / \mathrm{mm}$ was added at a concentration of $10 \mu \mathrm{g}$. $/ \mathrm{ml}$. Samples $(0.2 \mathrm{ml}$.) were taken and mixed with $1.8 \mathrm{ml}$. cold $0.5 \mathrm{~N}-\mathrm{HClO}_{4}$ and processed as above.

Counts were made with a Nuclear Chicago gas flow counter. No corrections for self-absorption were made. The results are reported as counts/min. above background.

$\beta$-Galactosidase assay. To $1.0 \mathrm{ml}$. samples of cell suspensions or supernatant fluids of ML 35 grown in salts + glycerol medium was added $4 \mathrm{ml}$. of $\mathrm{M} / 600 \mathrm{o}$-nitrophenyl$\beta$-D-galactoside (ONPG) in $0 \cdot 1 \mathrm{M}-\mathrm{Na}_{2} \mathrm{HPO}_{4}$ buffer ( $\mathrm{pH} 7$ ). After incubation at $37^{\circ}$ for sufficient colour development, the reaction was stopped by adding $5 \mathrm{ml}$. of $\mathrm{M}-\mathrm{Na}_{2} \mathrm{CO}_{3}$. Following centrifugation the optical density at $4.20 \mathrm{~m} \mu$ was determined; o-nitrophenol was used as a standard (Brock \& Brock, 1959b).

Viable counts. Viable counts were made by the pour plate method with nutrient agar; counts were made after incubation for $24 \mathrm{hr}$.

\section{RESULTS}

Antibiotic-induced lag occurs only when RNA synthesis can take place

In the following work, chloramphenicol and erythromycin gave essentially the same results, so for simplicity results are presented for chloramphenicol only. When chloramphenicol (50 $\mu \mathrm{g} . / \mathrm{ml}$.) or erythromycin (1000 $\mu \mathrm{g} . / \mathrm{ml}$.) was added to growing cultures of Escherichia coli, protein synthesis was almost completely inhibited, while RNA and DNA synthesis continued. When the organisms were washed several times to remove antibiotic and then resuspended in growth medium, there was a lag of 45-60 min. before growth resumed. This lag did not occur when the organisms were not treated with antibiotic, nor did it occur when growth was inhibited by withholding an essential amino acid or other nutrient such as a nitrogen, carbon or phosphorus source, rather than by antibiotic inhibition. It was not due to the killing of a portion of the population. Since the RNA synthesized in the presence of chloramphenicol differs in a number of ways from normal RNA (Horowitz et al. 
1958; Pardee et al. 1957), it seemed possible that the lag was due to the prior synthesis of this abnormal RNA (Hahn et al. 1957). To test this point, a mutant of $E$. coli was used which requires thymine + uracil for growth, since Barner \& Cohen (1958) had shown that withholding uracil prevented RNA synthesis without preventing DNA synthesis, and withholding thymine prevented DNA synthesis without affecting RNA synthesis. When growing cultures of this mutant were treated with antibiotic for $2 \mathrm{hr}$. in the presence or absence of either of these growth factors, and then tested for lag by resuspending them in antibiotic-free medium containing both growth factors, the following results were obtained: (1) With thymine + uracil present during antibiotic treatment there was a $1 \mathrm{hr}$. lag on recovery. (2) With thymine only present and uracil absent there was no lag. (3) With uracil only present and thymine absent there was a $1 \mathrm{hr}$. lag on recovery. (4) With neither thymine nor uracil present there was no lag. RNA synthesis did not take place in the absence of uracil, and DNA synthesis did not take place in the absence of thymine. These results indicate that, for the subsequent lag to occur, the cells must be able to synthesize RNA during antibiotic treatment.

As a further test of this point, uracil was added or withheld during the first or second hour of antibiotic treatment, or during both hours, or neither, and the amount of RNA synthesized was measured and correlated with the subsequent lag. These results are shown in Table 1 , in which the lag is given as the length of time

\section{Table 1. Synthesis of $R N A$ and induction of lag during chloramphenicol treatment in the presence or absence of uracil}

Escherichia coli 15 T-U-, in salts + glucose medium, thymine and chloramphenicol present in all.

\begin{tabular}{|c|c|c|}
\hline & $\begin{array}{l}\text { NA* synthesized } \\
\text { during } \\
\text { chloramphenicol } \\
\text { treatment } \\
(\mu \mathrm{g} . / \mathrm{ml} .)\end{array}$ & $\begin{array}{l}\text { Lag } \dagger \\
\text { (min.) }\end{array}$ \\
\hline No uracil & $\mathbf{0}$ & 0 \\
\hline Uracil, 2 hr. & 46 & $\mathbf{5 5}$ \\
\hline Uracil, 1st hr. & 33 & 45 \\
\hline Uracil, 2nd hr. & 38 & 30 \\
\hline
\end{tabular}

* Initial RNA, $35 \mu \mathrm{g} . / \mathrm{ml}$.

$\dagger$ Lag measured after reincubation in salts + glucose + thymine and uracil, given as time for o.D. to double minus the time for O.D. of logarithmically growing cells to double.

for the culture to double in optical density after resuspension, after subtracting the doubling time of a logarithmically growing culture (Lockhart, 1960). It can be seen that the lag was longer when uracil was present for $2 \mathrm{hr}$. than when it was present for $1 \mathrm{hr}$. Further, uracil present during the first hour induced a longer lag than uracil present during the second hour, even though approximately equal amounts of RNA were synthesized under both conditions. DNA synthesis occurred in all four treatments.

As a further correlation between RNA synthesis and lag, two mutants were used which required amino acids in addition to thymine and uracil. One of these was Escherichia coli 15 T-A-U- of Kanazir, Barner, Flaks \& Cohen (1959) which was isolated by them from $E$. coli 15 T- by an apparent one-step mutation to both 
arginine and uracil requirements, although the blockage in synthesis of both of these compounds is not complete. When arginine was withheld in the presence of uracil and thymine, no RNA synthesis occurred, apparently because of the obligatory coupling of RNA and protein synthesis under these conditions. However, when chloramphenicol or erythromycin was present, RNA synthesis occurred in the absence of arginine, even in arginine-starved cells. This is at variance with the observations of Pardee \& Prestidge (1956) and of Gros \& Gros (1958) that RNA synthesis did not occur in the absence of an essential amino acid, even in the presence of chloramphenicol. However, since this $\boldsymbol{E}$. coli mutant $\mathbf{T}-\mathbf{A}-\mathbf{U}-$ can form some arginine, this may be enough to support the synthesis of antibiotic-induced RNA even though it will not support normal RNA synthesis. When growing organisms of this mutant were treated with antibiotic in the absence of arginine, a $45 \mathrm{~min}$. lag was induced, while $21 \mu \mathrm{g} . / \mathrm{ml}$. of RNA were synthesized (Table 2). When both arginine and uracil were withheld, there was no antibiotic-induced RNA synthesis and no lag. This is further support for the idea that antibiotic-induced lag is due to the synthesis of abnormal RNA, since in this mutant, in the absence of arginine, only antibiotic-induced RNA can accumulate, and this accumulation leads to a subsequent lag.

A methionine-requiring mutant of Escherichia coli 15 T-U-, designated T-U-M-,

Table 2. Synthesis of $R N A$ and induction of lag during chloramphenicol treatment; arginine and uracil present or absent during antibiotic treatment

Escherichia coli $15 \mathrm{~T}^{-} \mathrm{A}^{-} \mathrm{U}^{-}$, in salts + glucose medium, thymine present in all during treatment; thymine, arginine and uracil present in all during recovery.

Conditions during treatment

Arginine + uracil

Arginine + uracil + chloramphenicol

Uracil, no arginine

Uracil + chloramphenicol, no arginine

No uracil, no arginine

No uracil, no arginine, chloramphenicol present

* Initial RNA, $35 \mu \mathrm{g} . / \mathrm{ml}$.

\begin{tabular}{|c|c|}
\hline $\begin{array}{c}\text { RNA* synthesized } \\
\text { during } \\
\text { treatment } \\
(\mu \mathrm{g} . / \mathrm{ml} .)\end{array}$ & $\begin{array}{l}\text { Lag† } \\
\text { (min.) }\end{array}$ \\
\hline 55 & 0 \\
\hline 21 & 45 \\
\hline $\mathbf{3}$ & 0 \\
\hline 21 & 45 \\
\hline 0 & 0 \\
\hline 2 & $\mathbf{0}$ \\
\hline
\end{tabular}

$\dagger$ Generation time of controls, 65 min.

Table 3. Synthesis of $R N A$ and induction of lag during chloramphenicol treatment; methionine present or absent during antibiotic treatment

Escherichia coli $15 \mathrm{~T}-\mathrm{U}^{-} \mathrm{M}^{-}$, in salts + glucose medium, thymine and uracil present in all during treatment; thymine, uracil and methionine present in all during recovery.

$\begin{array}{lcc} & \begin{array}{c}\text { RNA* synthesized } \\ \text { during } \\ \text { treatment } \\ (\mu \mathrm{g} . / \mathrm{ml} .)\end{array} & \begin{array}{c}\text { Lag† } \\ \text { (min.) }\end{array} \\ \text { Methionine } & \mathbf{9 3} & 0 \\ \text { Methionine + chloramphenicol } & 24 & 30 \\ \text { No methionine } & 7 & 0 \\ \text { No methionine, chloramphenicol present } 40 & 40\end{array}$

\footnotetext{
* Initial RNA, $58 \mu \mathrm{g} . / \mathrm{ml}$.

$\uparrow$ Generation time of controls, $70 \mathrm{~min}$.
} 
was isolated by the authors. This mutant could also synthesize some RNA in the absence of methionine, when chloramphenicol was present, and a lag was found on recovery (Table 3). A proline-requiring mutant, $E$. coli $\mathbf{B}_{4}$, did not synthesize antibiotic-induced RNA in the absence of proline and did not exhibit any antibioticinduced lag. It can therefore be concluded that antibiotic-induced lag occurs only when antibiotic-induced RNA is synthesized, and the lag may be related to the synthesis of some abnormal RNA. The results with the arginine- and methioninerequiring mutants show clearly that it is an antibiotic-induced RNA which is responsible for the lag, and not an excess of a normal RNA.

\section{Ability to synthesize new $R N A$ is not a prerequisite to recovery from antibiotic-induced lag}

Growing cultures of Escherichia coli 15 T-U- were treated with antibiotic for $1 \mathrm{hr}$. in glucose salts medium with thymine + uracil present. The organisms were then washed and resuspended in antibiotic-free medium from which uracil, thymine, glucose, ammonium chloride or phosphate was omitted. Ordinarily, organisms treated as above and resuspended in complete medium began to divide only after incubation for $45 \mathrm{~min}$. The requirement for various nutrients during this lag period was determined by withholding the nutrient for $45 \mathrm{~min}$., then adding it back, and determining whether the organisms started growing immediately (i.e. with no additional lag) or exhibited a further lag before growing. In each experiment, a control flask of antibiotic-treated organisms had the nutrient present during the lag. The lag was not increased in length significantly by withholding any of the nutrients essential for the synthesis of RNA, DNA or protein, namely, glucose, phosphate, ammonium salt, uracil or thymine. Since normal organisms do not grow or synthesize macromolecules when any of these nutrients is withheld, this seems to indicate that recovery from the antibiotic-induced lag is essentially a degradative process, probably involving the destruction of abnormal RNA. Since the degradative enzymes can operate in non-growing organisms (Horiuchi, 1959; Mandelstam, 1958), this interpretation seems justified. It also seems unlikely that the lag is due to a deficiency in any of the small molecules produced by the cell, since the addition of $0.5 \%(w / v)$ yeast extract during the recovery period did not shorten the lag.

\section{Synthesis of DNA and protein does not begin until the lag is over; but $R N A$ synthesis can begin immediately}

Preliminary measurements by chemical methods of RNA, DNA and protein during the recovery period revealed that synthesis of these macromolecules did not begin until the lag was over. However, chemical measurements would not indicate any turnover of macromolecules, such as degradation and resynthesis. Therefore, radio-isotope methods were used to follow these processes. Since the organism used, Escherichia coli 15 T-U-, has absolute requirements for both thymine and uracil, it was possible to measure synthesis of DNA and RNA by determining the incorporation of radioactive thymine and uracil into cold perchloric acid-insoluble material in whole organisms. Preliminary experiments comparing the isotope method with the chemical method indicated a close correspondence when logarithmically growing cultures were used. Presumably none of the radioactive thymine enters RNA, and 
only a small fraction of the radioactive uracil enters DNA, by way of cytosine. In every experiment a no-glucose control used to check for non-specific absorption always gave a negligible reading. As a measure of protein synthesis, the incorporation of ${ }^{14} \mathrm{C}$-proline and $\mathrm{Na}_{2}{ }^{35} \mathrm{SO}_{4}$ was determined.

Figure 1 shows the results of the incorporation studies with these isotopes. With thymine, proline or sulphate, there was a lag in the incorporation of isotope in chloramphenicol-treated organisms, and this lag paralleled the lag in growth. However, incorporation of ${ }^{14} \mathrm{C}$-uracil differed from the other isotopes in one important

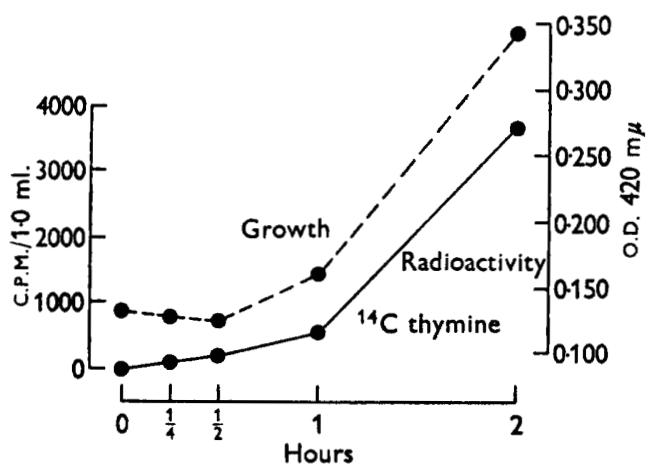

A

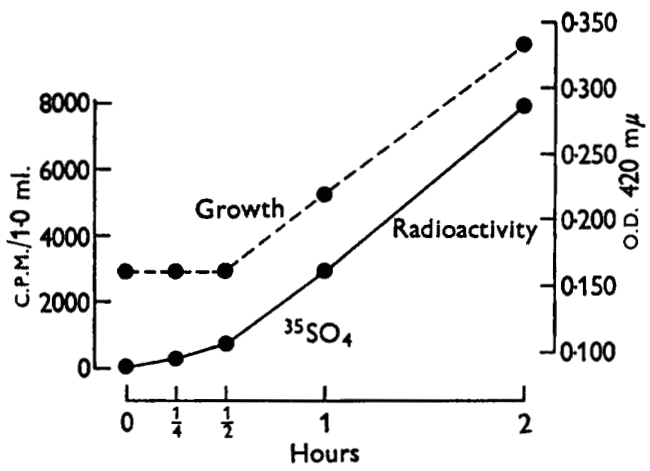

C

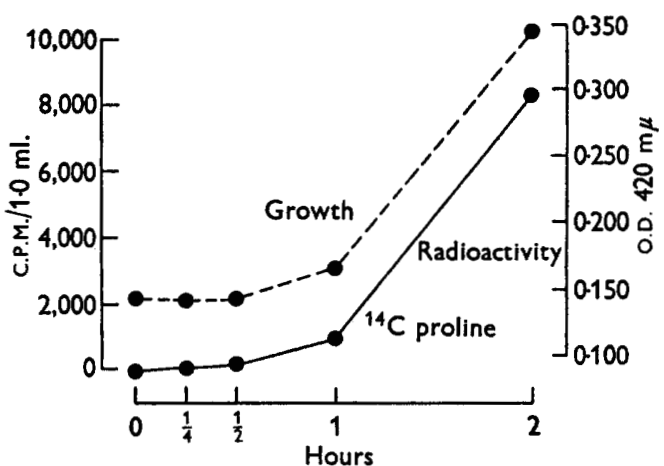

B

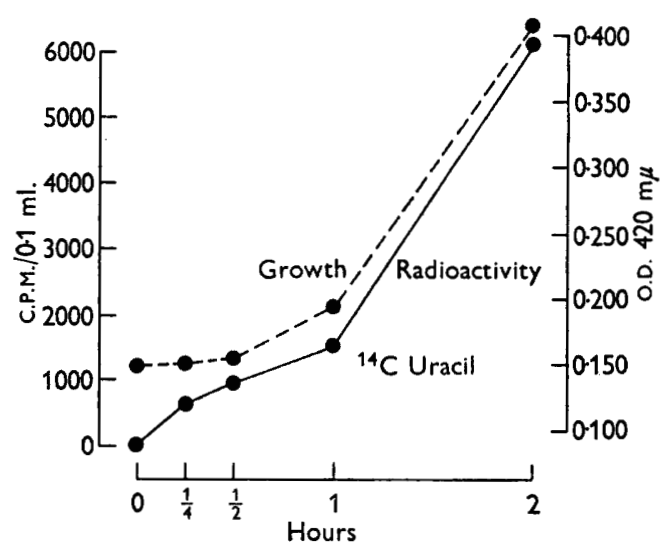

D

Fig. 1. Growth of $E$. coli $15 \mathrm{~T}-\mathrm{U}^{-}$and incorporation of: (A) radioactive thymine, (B) radioactive proline, (C) radioactive sulphate, and (D) radioactive uracil during chloramphenicol-induced lag. - - - - Growth; __, radioactivity.

respect. There was an initial rapid increase in uracil incorporation, followed then by a slower rate, and this was followed by the normal rate of incorporation after growth had resumed. Although brief, this initial rapid increase was reproducible. The interpretation is advanced that the antibiotic-treated organisms, although unable to synthesize DNA or protein during the lag, were able to synthesize RNA, and that the initial rapid increase in incorporation was due to synthesis of new RNA. However, during the antibiotic treatment the organisms have accumulated RNA which is being degraded, and soon this degradation provides sufficient_non-radio- 
active RNA precursors to dilute out the isotopic uracil, and the synthesis of new RNA probably then occurs predominantly from the non-radioactive sources. Only after all of this RNA was degraded, and the lag was overcome, was radioactive uracil again incorporated at a maximum rate. This interpretation supports the idea advanced by others (Kjelgaard, Maaløe \& Schaechter, 1958) that when there is a shift in growth rate from low to high, RNA synthesis occurs in advance of this shift and apparently provides the higher concentrations of RNA necessary in the cell to support this new growth rate. It is concluded therefore that the synthesis of RNA can begin immediately in the non-growing cells, whereas DNA and protein synthesis can occur only after the lag is overcome.

\section{Loss of antibiotic-accumulated RNA may occur under some conditions}

In earlier work on antibiotic-induced lag it was reported (Hahn et al. 1957; Neidhart \& Gros, 1957; Horowitz et al. 1958) that the RNA which accumulated was degraded and excreted before growth resumed. It was suggested by these workers that this excretion was essential to the recovery process. In the present experiments, when the antibiotic-treated organisms were resuspended in complete growth medium, there was no evidence that the degradation of RNA was followed by the excretion of RNA precursors during the lag. However, when the organisms were suspended in non-growth medium, such as phosphate buffer, there was a marked loss of RNA from the cells during the recovery period. This observation is not completely at variance with earlier work, since Neidhardt \& Gros (1957) and Horowitz et al. (1958) only studied excretion under non-growing conditions, and Hahn et al. (1957) used much longer periods of antibiotic treatment which may have brought about more drastic metabolic derangements. Horiuchi, Sunakawa \& Mizuno (1958) also found in Escherichia coli B that antibiotic-induced RNA was excreted under non-growing conditions but not under growing conditions.

In the present work it was noted that whenever there was a loss in RNA there was a sharp decrease in optical density. This decrease in optical density seemed to indicate that antibiotic-treated organisms were lysing when they were not growing and not lysing when they were growing, and that excretion of RNA degradation products was not occurring, but that a complete lysis and release of all of the cell contents occurred in some of the organisms. More detailed studies showed this idea to be wrong; the results to be presented below show that antibiotic-induced RNA was degraded and the degradation products excreted under non-growing conditions, whereas under growing conditions they were immediately incorporated into new RNA. The decrease in optical density was not due to lysis but to some other change in the morphology of the cells.

It was found that the membrane filter technique did not distinguish between high-molecular weight RNA within cells or in lysates. Thus, when cells were labelled with ${ }^{14} \mathrm{C}$-uracil in the absence of antibiotic, lysed with lysozyme and ethylene diaamine tetracetic acid, and the lysates diluted into cold perchloric acid and filtered, all of the radioactivity was retained by the filter, and the counts obtained were the same as when unlysed organisms were used. Treatment of lysates for $30 \mathrm{~min}$. with $0 \cdot 1 \mathrm{~N}-\mathrm{NaOH}$ at $0^{\circ}$ almost completely degraded the RNA of these lysates, so that the radioactivity then passed through the filter. These results showed that the mem- 
brane filter technique would withhold high molecular weight RNA whether within cells or free, whereas low molecular weight materials passed through the filter.

Two series of experiments were set up. In the first, the RNA of cells was labelled by growth for three generations in radioactive uracil in the absence of chloramphenicol. The organisms were then washed and suspended in growth medium with chloramphenicol and cold uracil for $1 \mathrm{hr}$., then washed again to remove antibiotic and suspended in phosphate buffer or growth medium with antibiotic. The optical density of the suspension was measured periodically, and samples were taken for membrane filtration. It can be seen in Fig. $2 a$ that in growth medium there was the usual lag on recovery but no loss of radioactivity. In phosphate buffer there was a marked decrease in optical density in the suspension of antibiotic-treated organisms but no loss in radioactivity. This shows that preformed RNA was not degraded during recovery, although the decrease in optical density seems to indicate some antibiotic-induced change in the organisms.

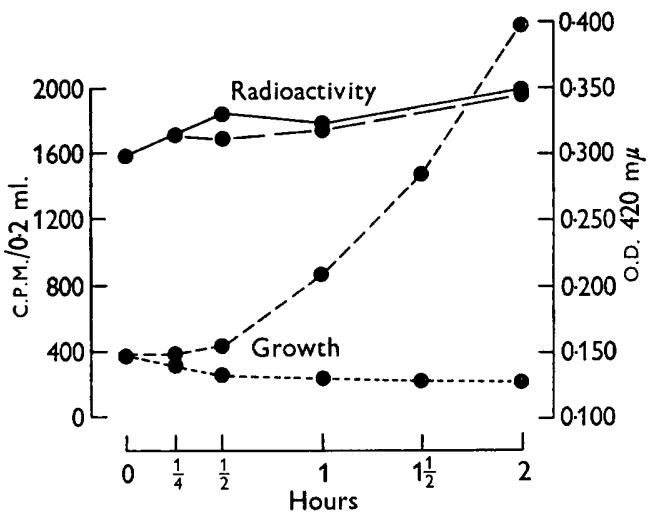

$\boldsymbol{a}$

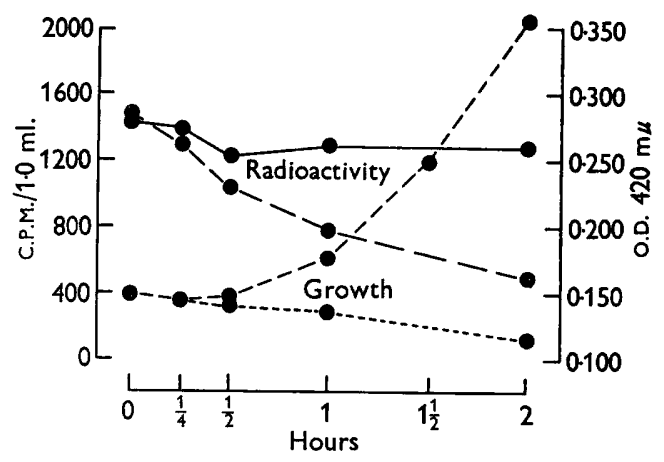

b

Fig. 2. Growth of Escherichia coli $15 \mathrm{~T}-\mathrm{U}^{-}$and changes in radioactivity after treatment with chloramphenicol. (a) Cells labelled with ${ }^{14} \mathrm{C}$-uracil before chloramphenicol treatment, then $1 \mathrm{hr}$. chloramphenicol treatment, then recovery in antibiotic-free salts + glucose medium or phosphate buffer. (b) Cells labelled with ${ }^{14} \mathrm{C}$-uracil during $1 \mathrm{hr}$. chloramphenicol treatment, then recovery in antibiotic-free salts + glucose medium, or phosphate buffer. Graphs represent growth and retention or loss of radioactivity. - Radioactivity, cells suspended in salts + glucose; - - radioactivity, cells suspended in phosphate buffer; - - - , growth, cells suspended in salts + glucose ; -.---., growth, cells suspended in phosphate buffer.

In the second series of experiments, the RNA was labelled by having ${ }^{14} \mathrm{C}$-uracil present during a $1 \mathrm{hr}$. chloramphenicol treatment and the organisms then washed and resuspended in growth medium or in phosphate buffer and the optical density and loss of radioactivity determined. In Fig. $2 b$ it can be seen that in growth medium there was the usual lag on recovery but only a slight and transitory loss in RNA. In phosphate buffer there was a definite decrease in optical density and a marked loss of radioactivity. These results show that antibiotic-accumulated RNA was degraded to low molecular weight material and lost from the organisms when they were suspended in non-growing conditions. Under growing conditions there was only a negligible loss in radioactivity, so the degraded material must have been immediately incorporated into new RNA. This immediate re-incorporation is in 
agreement with the results above which showed that RNA synthesis began immediately, even during the lag period. Thus antibiotic-accumulated RNA was degraded during recovery, whereas normal RNA was not degraded even in antibiotic-treated organisms.

The decrease in optical density of suspensions of antibiotic-treated organisms in phosphate buffer seemed to indicate that lysis occurred in these organisms. However, viable counts of control and antibiotic-treated organisms of samples taken at intervals up to $2 \mathrm{hr}$. in phosphate buffer indicated no loss in viability which would be expected to accompany lysis (Table 4). As a more sensitive measure of possible lysis the hydrolysis of ONPG by a $\beta$-galactosidase-constitutive, permease-less mutant of Escherichia coli (ML 35) was measured (Brock \& Brock, 1959b). In addition, the enzyme activity of supernatant fluids from such organisms was measured. No increase in rate of hydrolysis was noted in antibiotic-treated organisms as compared to control organisms after $1 \mathrm{hr}$. in phosphate buffer, although most of the radioactivity was lost during this $1 \mathrm{hr}$. treatment, as shown in Fig. $2 b$. Thus there was no evidence that the decrease in optical density was due to frank lysis, or to a markedly altered permeability of the cells brought about by the antibiotic treatment. An alternative explanation is that the decrease in optical density was due to an increase in pool materials because of an accumulation of RNA degradation products. This would result in an increased osmotic pressure in the cell, bringing about an increase in diffusion of water into the cells, leading to a swelling of the cells and a decrease in optical density. This latter explanation seems the more likely.

\section{Table 4. Viable counts}

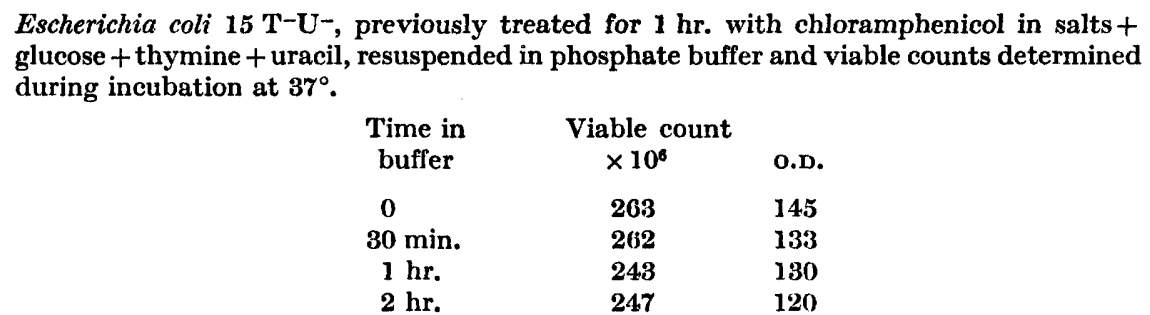

\section{DISCUSSION}

The results of the present work help to clarify the problem of antibiotic-induced lag and antibiotic-induced RNA synthesis in Escherichia coli. It appears that the lag occurs only under conditions where antibiotic-induced RNA synthesis occurs, and when this antibiotic-induced RNA synthesis is prevented by any means (such as deprivation of a nutrient essential for its synthesis) no subsequent lag occurs. Interesting in this regard are the results with the arginine- and methionine-requiring mutants which did not synthesize normal RNA but which synthesized antibioticinduced RNA in the absence of added arginine and methionine, respectively, and which exhibited a subsequent lag after this synthesis. A proline-requiring mutant which did not synthesize chloramphenicol-induced RNA in the absence of proline exhibited no lag on recovery.

The observations of Borek \& Ryan (1958) are pertinent to this discussion. They found that in one particular methionine-requiring mutant of Escherichia coli, RNA 
was synthesized in the absence of methionine, and the RNA-rich organisms exhibited a lag after methionine was added before growth was resumed. (No antibiotic was added in this experiment.) This lag may have been due to the accumulation of abnormal RNA which had to be degraded before growth could be resumed. The results of Borek \& Ryan may be analogous to the present results concerning antibiotic-induced lag.

Since no requirements for energy-yielding or essential nutrients were found, recovery from the antibiotic-induced lag appears to be a degradative process in which hydrolytic enzymes cleave abnormal RNA. During the recovery period, DNA and protein synthesis did not occur, but the organisms appeared to be able to synthesize RNA during the lag while RNA was being degraded, provided that energy sources and the RNA precursors were supplied. This new RNA synthesis is probably not essential for recovery, since recovery occurred in the absence of many nutrients essential for new RNA synthesis. However, the fact that RNA synthesis occurred during the lag (even though not required) may be a further indication of the hierarchy of macromolecular syntheses for growing organisms (Kjelgaard et al. 1958).

Excretion of the degradation products is not a requirement for recovery, since when the cells were suspended in growth medium, these degradation products were immediately incorporated into new high molecular weight RNA. The degradation products apparently accumulated both within the cell and in the supernatant fluid under non-growth conditions (Neidhardt \& Gros, 1957). The accumulation within the organisms was probably responsible for the decrease in optical density of suspensions that took place in organisms under non-growth conditions, since there was no evidence of lysis.

An unanswered question from this and earlier investigations is: why does the lag occur? It is not a sufficient explanation to state that this is abnormal RNA and thus prevents growth. Why is this RNA abnormal? As yet there is no answer to this question, since so much is lacking about our understanding of the macromolecular strategy of normal growth processes.

This work was supported by grant E-2036 from the U.S. Public Health Service.

\section{REFERENCES}

Barner, H. D. \& Cohen, S. S. (1958). Protein synthesis and RNA turnover in a pyrimidine-deficient bacterium. Biochim. biophys. Acta, 30, 12.

Borek, E. \& Ryan, A. (1958). Studies on a mutant of Escherichia coli with unbalanced ribonucleic acid synthesis. II. The concomitance of ribonucleic acid synthesis with resumed protein synthesis. J. Bact. $75,72$.

Brock, T. D. \& Brock, M. L. (1959a). Similarity in mode of action of chloramphenicol and erythromycin. Biochim. biophys. Acta, 33, 274.

Brock, T. D. \& Brock, M. L. (1959b). Effect of novobiocin on permeability of Escherichia coli. Arch. Biochem. Biophys. 85, 176.

Brock, M. L. \& Brock, T. D. (1960). Recovery of Escherichia coli after antibiotic treatment. Bact. Proc. 1960, p. 178.

Burton, K. (1956). A study of the conditions and mechanism of the diphenylamine reaction for the colorimetric estimation of deoxyribonucleic acid. Biochem.J.62, 315.

Chargaff, E. \& Davidson, J. N. (1955). The Nucleic Acids, vol. 1, p. 301. New York: Academic Press Inc. 
Gros, F. \& Gros, F. (1958). Rôle des acides amines dans la synthèse des acides nucléiques chez Escherichia coli. Exp. Cell Res. 14, 104.

Hahn, F. E., Schaechter, M., Ceglowski, W. S., Hopps, H. E. \& Ciak, J. (1957). Interrelations between nucleic acid and protein biosynthesis. I. Synthesis and fate of bacterial nucleic acids during exposure to, and recovery from, the action of chloramphenicol. Biochim. biophys. Acta, 26, 469.

HorIUCHI, T. (1959). RNA degradation and DNA and protein synthesis of $E$. coli in a phosphate deficient medium. J. Biochem. (Tokyo), 46, 1467.

Horiuchi, T., Sunakawa, S. \& Mizuno, D. (1958). Stability of nucleic acid synthesized in the presence of chloramphenicol in $E$. coli under growing and resting conditions. J. Biochem. (Tokyo), 45, 875.

Horowitz, J., Lombard, A. \& Chargaff, E. (1958). Aspects of the stability of a bacterial ribonucleic acid. J. biol. Chem. 233, 1517 .

Kanazir, D., Barner, H. D., Flaks, J. G. \& Cohen, S. S. (1959). Some physiological and genetic properties of a strain of Escherichia coli requiring thymine, arginine and uracil. Biochim. biophys. Acta, 34, 341.

KJelgaArd, N. O., Maliøe, O. \& Schaechter, M. (1958). The transition between different physiological states during balanced growth of Salmonella typhimurium. J. gen. Microbiol. 19, 607.

Lockhart, W. R. (1960). Measurement of generation lag. Canad. J. Microbiol. 6, 381.

Lowry, O., Rosebrough, N. J., Farr, A. L. \& Randall, R. J. (1951). Protein measurement with the Folin phenol reagent. J. biol. Chem. 193, 265.

MANDELSTAM, J. (1958). Turnover of protein in growing and non-growing populations of Escherichia coli. Biochem. J. 69, 110.

NeidhardT, F. C. \& Gros, F. (1957). Metabolic instability of the ribonucleic acid synthesized by Escherichia coli in the presence of chloromycetin. Biochim. biophys. Acta, 25, 513.

Pardee, A. B., Paigen, K. \& Prestidge, L. S. (1957). A study of the ribonucleic acid of normal and chloromycetin-inhibited bacteria by zone electrophoresis. Biochim. biophys. Acta, 23, 162.

Pardee, A. B. \& Prestidge, L. S. (1956). The dependence of nucleic acid synthesis on the presence of amino acids in Escherichia coli. J. Bact. 71, 677.

Roberts, R. B., Abelson, P. H., Cowie, D. B., Bolton, E. T. \& Britten, R. J. (1957). Studies of Biosynthesis in Escherichia coli, ch. 1. Washington, D.C.: Carnegie Inst. 